\title{
METHODS OF FINANCIAL STATEMENT ANALYSIS FOR NON-GOVERNMENTAL ORGANISATIONS
}

\author{
Kristaps Zdanovskis, Irina Pilvere \\ Latvia University of Live Sciences and Technologies, Latvia \\ kristaps.zdanovskis@gmail.com
}

\begin{abstract}
Public participation is needed for nongovernmental organisations (NGO) to function and exist, as the public plays the role of investors by supporting the NGOs financially and thereby providing a quorum needed for the organisation to operate and make decisions. NGOs provide services for defending public interests, and the NGOs members carefully assess their gains from involvement or participation continuation in public organisations, just as if choosing a good or service for consumption. The level of society activity in NGOs sector is low in Latvia comparing with the Western world. To increase it, it is required to contribute to the public's trust and NGOs transparency. Organisational performance analysis is one of the ways how to provide members with information on performance and funding use, as the members of NGOs wish to be sure that their membership fees and other financial support are effectively used to achieve their goals and defend the interests of their members.

The research aims to analyse financial analysis methods used in the NGO sector. The research tasks were set: 1) to analyse the substance of financial analysis of NGO, and 2) to identify shortcomings for a comprehensive analysis of NGO. The research has found that as public participation in NGOs increases, it becomes increasingly important to provide financial transparency in the NGO sector in order to contribute to the public's trust in the NGOs and make it possible to verify the consistency of funding use with the organisation's goals and performance.
\end{abstract}

Key words: non-governmental organisations; financial analysis; statement analysis; financial ratios.

\section{Introduction}

The origins of financial analysis, according to some bibliographical sources, date back to the $15^{\text {th }}$ century, as it was needed to identify the financial contribution an investment in securities made. Financial analysis is employed throughout the world, and the long history of it is also evidenced by findings of researchers in economics that are still present in modern bibliographical sources (Phillips et al., 2012). Regardless of the place in the world where an analysis is done, it maintains its goal of providing comprehensive information on the financial status of the entity. The goal of any economic entity is to make profit, and financial analysis is a way how to achieve it prudently. Despite the fact that a good or service is sold, and the customer pays for it on a certain date, the obligations assumed for the period between the sale and the payment moment have to be met as well (Morris, 2011). For this reason, bibliographical sources often describing financial analysis as the analysis to predict bankruptcy or monitor financial health are used (Tian \& Yu, 2017). Most often, the public believes that financial analysis is needed only for banks to make sure the enterprise has enough assets to meet its liabilities, or for investors to verify that the enterprise is going to pay dividends and its share price might be expected to increase. In reality, the results of a financial analysis are useful to a broad circle of individuals, including employees, managers, competitors, state administration, etc. (Phillips et al., 2012). Financial analysis is part of a set of activities focusing on trends in the industry, innovation, customer satisfaction, market share and other factors. In addition to the financial focus, a system for assessing the nonfinancial aspect has to be created, depending on the specifics of the entity analysed as well as the technological contribution, quality, innovation, etc. (Eccles, 2008). Financial analysis is not limited to conventional calculation methods in assessing liquidity, stability, asset turnover and profitability. The key functions of analysis have remained, yet mutual competition encourages combining new calculation methods, designing new operational strategies and, in addition to financial performance indicators, trends in the industry and economy have to be predicted. A standardised calculation methodology is mainly employed by statistical and industry trend reports.

Most scientific literature sources state that enterprises use financial analysis for making higher profits. An adapted calculation methodology could be employed for performing a financial analysis for NGOs having no purpose of making profit. In both cases, funds are needed for the operation of an organisation, which have to be allocated prudently. An entity's annual financial reports and their annexes are used for performing basic calculations. The scope of analysis depends on available information. Publicly available information allows performing a financial analysis by conventional methods, while the managers of the entities analysed, who had access to specific data, had an opportunity to make a detailed analysis. Financial reporting and accounting are regulated by the relevant legal framework, and due to mutual competition among the entities, only minimum information stipulated by the legal framework is publicly available. For this reason, to perform a complete analysis of the performance of an organisation, the results have to be compared with the average in the sector or 
industry concerned or benchmarked against other organisations. The comparison could be done by using statistical data on the sector or industry concerned or reports of each individual organisation.

The research aims to analyse financial analysis methods used in the NGO sector. To achieve the aim, the following specific research tasks were set:

1. To analyse the substance of financial analysis of the NGO;

2. To identify shortcomings for a comprehensive analysis of the NGO.

\section{Materials and Methods}

To carry out the research, the authors used relevant research papers, information provided by the Central Statistical Bureau (CSB), laws of the Republic of Latvia and Cabinet regulations and the Lursoft database. The research used the following methods: monographic, descriptive, analysis and synthesis as well as logical construction. Described financial analysis methods are compared with averages for the NGO sector and agricultural NGO financial performance indicators. The averages for the NGO sector were acquired from the study by the Latvian Civic Alliance (2016), while the data on agricultural NGO financial performance were acquired by analysing NGO annual reports available in the Lursoft database. The research analysed five largest horizontal level national agricultural organisations in Latvia that were active in the Advisory Council of the Ministry of Agriculture for agricultural nongovernmental organisations, which is an advisory and coordinating collegial institution. Its purpose is to contribute to the agricultural industry through balanced and sustainable policies by assuming shared responsibility for agricultural and rural development (Zemkopības ministrija, 2017).

\section{Results and Discussion}

\section{Substance and purpose of financial analysis}

An analysis of financial reports or financial analysis allows assessing the financial status of an enterprise by using available current and historical data - the enterprise's current and future financial status - for making economic decisions (Robinson, 2009). Basically, anyone of us who does financial planning deals with financial analysis daily, only the extent and the goals to be achieved differ.

The purpose of financial analysis is to give comprehensive insight into an entity or industry in order to provide motivational information to potential cooperation partners. Annual reports used in financial analysis contain historical information that could not be changed, which allows critically assess the situation in the enterprise and acquire a safe assessment (Jegers, 2013). Financial analysis has to have two major characteristics concerning information - relevance and faithful representation. Information is relevant if it makes a difference in decision making, and it is a faithful representation if it fully depicts the economic substance of business activities. It is more useful if it is comparable, verifiable, timely and understandable (Phillips et al., 2012).

Most often, the users of financial reports and results of a financial analysis as the key source of information are banks and investors who make decisions on cooperation with the enterprise (Phillips et al., 2012).

Sometimes, however, the opportunities given by annual reports and financial analyses are underestimated (Figure 1); the reports have to be analysed by the board to verify how much the organization raised versus the expectation for the period; by creditors to verify how much their donation represents as a percentage of the total amount raised (Haber \& Schryver, 2019); by national institutions to project tax revenues and plan tax rate change, etc. The financial stability of an enterprise is determined by the solvency and competitiveness of it, which is characterised by an opportunity for it to steadily develop and meet its liabilities. An analysis of performance has to have a possibility to compare the current performance with that in previous periods and with competitor performance. Therefore, annual reports are produced by a common methodology. In Latvia, the key source of information for financial analysis is an enterprise's annual financial report, which is a

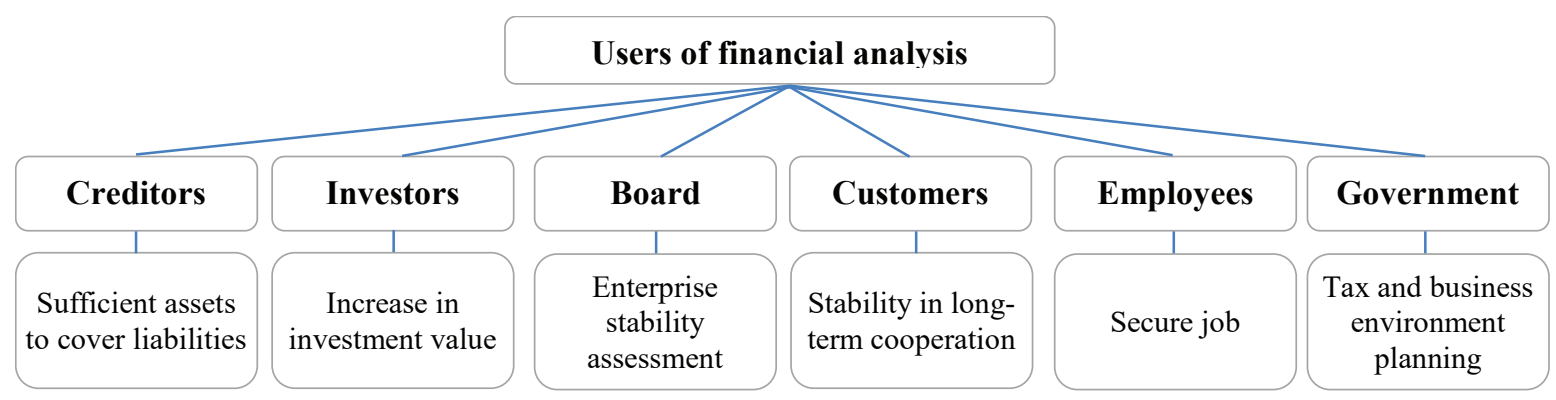

Figure 1. Users of financial analysis and their gains from the analysis results.

Source: authors' construction based on Phillips et al. (2012) and Haber \& Schryver (2019), 2019. 
publicly available document that contains information on financial performance as at the beginning and end of a year. Small legal entities, including associations and foundations, in Latvia are organising the accounting process in accordance with national laws and Cabinet regulations, not using international accounting standards. The main regulations for NGOs in Latvia are the Law on Accounting and Cabinet regulation No. 808 of $2006-$ Regulations Regarding Annual Reports to Be Submitted by Associations, Foundations and Trade Unions (Leibus et al., 2018).

The bibliographical sources have insufficiently focused on financial analyses of the NGO sector in comparison with those of enterprises. The importance of NGOs financial analysis has same as enterprises. Here should remember the key differences, that the purpose of any NGO is not profit-making comparing with enterprises; however, the investors and NGO members, just like in the case of enterprises, are interested in the way funds are allocated and in returns concerning the defence of public interests.

Financial performance analysis in the NGO sector in Latvia

The NGOs must follow their financial stability, because they are responsible for their members for the funds they spend and achieved results, as well as The Associations and Foundations Law (2004) stipulates that nongovernmental organisations are responsible for their liabilities just like other legal entities. The right selected financial statement analysis methodology is a way to improve the transparency. The differences in balance sheet items between NGOs and enterprises (Table 1) give an explanation why it is necessary to use different calculation equations. An enterprise's financial report consists of a balance sheet and a profit/loss account, while an annual report of an association or foundation consists of a balance sheet and a revenue/expenditure statement (Leibus et al., 2018). In both cases, a balance sheet maintains its key properties - the assets indicate available funds, while the liabilities show the origin of the available funds. Both balance sheet sides are equal, and the balance of each item is given for the last date of the reporting period. Considerable differences in balance sheet items for the liabilities side are observed. An expanded balance sheet for an enterprise is approximately twofold longer than that for associations and foundations, giving more accurate explanations for the origin of funds or creditors. The key items of equity capital for an enterprise represent share capital, reserves, retained earnings of the accounting period and earnings of previous years, whereas the equity capital of associations and foundations consists of three items - the basic fund, the reserve fund and target funds. The basic fund represents long-term investment, while the reserve fund is the surplus of revenues after expenses have been deducted. The use of target funds is important for large associations engaged in various fields of activity if donors wish the funds to be allocated for a particular activity. In contrast, the use of funds by small associations can indicate the wish of their members to make the allocation of funds more transparent. The assets items are almost the same for NGOs and enterprises, yet the assets of associations often consist of cash, fixed assets and intangible assets, whereas for enterprises a significant item is inventories that represent available goods to be sold to make profits or a source of finance in case of financial instability.

A profit or loss account for enterprises is much more important than a revenue and expenditure statement for associations and foundations, as it

Table 1

\section{Comparison of balance sheet items between associations, foundations and enterprises}

\begin{tabular}{|c|c|c|}
\hline & Associations, foundations & Enterprises \\
\hline $\begin{array}{l}0 \\
0 \\
0 \\
0 \\
⿱ 亠 䒑\end{array}$ & $\begin{array}{l}\text { Long-term investment: } \\
\text { I. Intangible assets } \\
\text { II. Fixed assets } \\
\text { III. Long-term financial investment } \\
\text { Current assets: } \\
\text { I. Inventories } \\
\text { II. Receivables } \\
\text { III. Securities } \\
\text { IV. Cash }\end{array}$ & $\begin{array}{l}\text { Long-term investment: } \\
\text { I. Intangible assets } \\
\text { II. Fixed assets, investment property un biological assets } \\
\text { III. Long-term financial investment } \\
\text { Current assets: } \\
\text { I. Inventories } \\
\text { II. Receivables } \\
\text { III. Short-term financial investment } \\
\text { IV. Cash }\end{array}$ \\
\hline 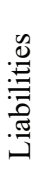 & $\begin{array}{l}\text { I. Funds: } \\
\text { 1. Basic fund } \\
\text { 2. Target funds } \\
\text { 3. Reserve fund } \\
\text { II. Long and Short-term debt }\end{array}$ & $\begin{array}{l}\text { Equity capital: } \\
\text { 1. Share capital } \\
\text { 5. Reserves } \\
\text { 6. Retained earnings or uncovered losses } \\
\text { Long and Short-term debt }\end{array}$ \\
\hline
\end{tabular}

Source: authors' construction based on Regulation Regarding the Associations' and Foundations' Annual Financial Statements (2006) and Regulation Regarding the Conduct and Organisation of Accounting (2003), 2019. 
shows the economic performance of an enterprise aimed at making profits and ensuring the operation of the enterprise. In contrast, the NGO revenue and expenditure statement gives informative insight into the key items of revenue and expenditure. The key purpose of NGOs is not to have an excess of revenues over expenditures but to perform the tasks defined by their members, and if the expenditures exceed the revenues, a higher membership fee can offset the gap. Additionally, the NGO sector is advised to the extent possible to have an excess of revenues in order to safeguard themselves against cost and price level fluctuations.

NGOs are part of society, and the governments are interested to improve society engagement that indicates a positive cooperation between both parts in democratic states. It is for this reason, that NGOs receive a lot of benefits comparing with enterprises. These benefits are sometimes used unfairly, and different methods of performance analysis incl. financial analysis is a way how to keep a positive image of NGOs.

The diversity of available information has to be considered when choosing a calculation methodology for financial analysis. Various equations could be designed, yet it has to be taken into account that publicly available information can less explain the performance of and processes in the NGO than insider information can do. The authors conclude that the study by the Latvian Civic Alliance (2016) indicated that some items of revenue/expenditure statements such as Other Revenue or Other Expenditure can reach even $30 \%$ of the total, and the Regulation Regarding the Associations' and Foundations' Annual Financial Statements (2006) does not prescribe that the mentioned items have to be detailed. That is why it is not possible to identify the source of finance or the purpose of expenditure for a considerable amount of funds by the use of publicly available information. Calculating performance indicators, it has to be considered whether the data are objective, and it is not useful to apply a lot of equations to acquire the results on which no conclusions could be made.

Overall, financial performance indicators could be divided into the following four categories: 1) liquidity, 2) stability, 3) asset turnover, 4) profitability indicators, or according to their broad types: revenue, expenditure and administrative as well as balance sheet indicators (Robinson, 2009).

LIQUIDITY RATIO is one of the most popular financial analysis indicators, which belongs to balance sheet indicators. Each Ashley \& Faulk (2010); Holman, Ihrke \& Grasse (2010), Hammond (2015) has defined a liquidity ratio in a different way, yet the basic idea is the same - it is a ratio of current assets to liabilities. Totally, there are at least four types of liquidity ratios, as stated by Bogužs (2010), and the calculation results are affected by the balance sheet items used. The authors point out that the standard equation for liquidity ratio calculation is the most appropriate for the NGO sector. The calculation could use various equations, yet differences in the results are insignificant. According to the study by the Latvian Civic Alliance (2016), the key current assets items of the NGO sector are cash and receivables, 53.6\% and $31.9 \%$, respectively, as the other assets items such as inventories (materials and goods) and securities have low proportion in the total assets. In the NGO sector, the proportion of long-term debt is only $5 \%$; however, an analysis of balance sheets of agricultural enterprises reveals a lack of long-term debt. A liquidity ratio shows the financial stability of an organisation and allows assessing the financial possibility to cover liabilities. In Latvia, according to the study by the Latvian Civic Alliance (2016), the ratio for NGOs is 1.6 or within normal limits.

However, the above-mentioned equation for calculating a liquidity ratio for agricultural NGOs in Latvia has not been employed, as the proportion of their liabilities, on average, was $7.9 \%$ of the total balance sheet liabilities and their current assets reached 94.9\%, of which $90 \%$ was cash, and the remaining $10 \%$ was debt and inventories. The NGOs managed to save relatively a lot of financial resources, and they had almost no short-term debt. This means a liquidity ratio for the agricultural NGOs can reach several hundreds. In the situation where NGOs have a low proportion of liabilities, the authors suggest using a ratio of current assets to key expenditure items. Unlike a convention enterprise, an NGO's main resource is its employees being remunerated for their work. The main costs of organisations are also technical expenditures, yet the technical expenditures, compared with remuneration, are more elastic, and the quality of services provided by the organisations is not affected by reduction in the technical expenditures. For agricultural NGOs, $a$ ratio of cash to remuneration expenditures indicates the capability of the NGOs to steadily remunerate their employees for a period by use of disposable funds. The lowest ratio was half a year, whereas the highest was 2.6 years. A liquidity ratio similar to the authors' one was suggested by Hammond (2015) who proposed calculating a ratio of assets to average monthly expenditures to identify the period over which the organisation is capable to ensure its operation by means of disposable assets.

STABILITY RATIO is similar to the liquidity ratio; it shows the extent of NGO independence from creditors. Chiang (2016) suggests calculating it as $a$ ratio of liabilities to assets or liabilities to funds. The former one shows the proportion of borrowed capital in the organisation total, while the latter one shows 
the proportion of liabilities in the total funds or equity capital. It could be expressed as a ratio or a percentage, which does not change the substance of it, as it is a typical structural indicator. A very high ratio could create problems regarding the future solvency of the organisation or borrowing funds. For example, Bogužs (2010) has defined a stability ratio as a ratio of funds to the balance sheet total, yet the authors point out that basically it is the same indicator, which has been reversed, as total liabilities are equal to total assets, and in the NGO sector liabilities consist only from funds and liabilities (Latvian Civic Alliance, 2016).

ASSET TURNOVER and PROFITABILITY $A N A L Y S E S$, unlike conventional financial analyses, are not appropriate for the NGO sector. Technically, the calculation methods could be adapted. A ratio of asset turnover shows how effectively disposable assets are used. In the NGO sector, however, the key balance sheet items are current assets, of which the key one is cash, and debts. The situation with profitability analyses is similar, as profitability indicates the efficiency of performance, showing profit earned on the assets invested. The purpose of NGOs is not profit-making, yet the NGOs are not prohibited to perform economic activities, including making profit that is used to cover expenditures related to their basic activity, project implementation, etc. Accordingly, to some extent, it is possible to perform asset turnover and profitability analyses for NGOs, identifying returns on the resources utilised, yet it could not be done by using only publicly available information annual reports.

To some extent, NGOs have to operate profitably, with an excess of revenue, in order to save funds for unexpected expenditures or revenue fluctuations. One of the ways of calculating profitability is to identify an excess of revenue over expenditures or subtract expenditures from revenues; the result shows whether the NGO had a surplus of funds in the reporting year.

The scientific literature most often refers to a profitability ratio such as a ratio of revenue less expenditures to total revenue. Ashley \& Faulk (2010); Holman, Ihrke \& Grasse (2010); Hammond (2015) gave three terms for this ratio: 1) Full cost coverage; 2) Operating margin; and 3) Savings indicator. This ratio is expressed as a percentage showing the organisation's capability not only to operate in a long-term and cover direct and indirect expenditures by its revenue but also to make provisions for unexpected expenditures. Too large provisions might indicate inefficient use of funds that could be allocated for other projects.

Operational reserves show also profitability ratio, which indicate whether financial resources are sufficient to ensure further activities without borrowing from external sources, and is calculated as follows: available assets, except equity capital, are divided by total cost. An operating reserves' ratio has to be at least 0.25 or at least three-month expenditures have to be covered. This ratio indicates how many months an organisation can ensure its operation without borrowing from external sources. According to the Latvian Civic Alliance (2016), the self-sufficiency ratio for the NGO sector of Latvia is estimated at $33.9 \%$, and at least four-month expenditures could be covered by the disposable funds of the NGOs. The authors point out that this ratio does not play an essential role in specifying the financial capacity of the NGO if the NGO has a safe and balanced cash flow. An essential role is played by the ratio if the $\mathrm{NGO}$, for example, participates in EU-funded project proposal competitions; the project costs are covered after the project has been completed or after submitting an intermediate report - before the project costs have to be covered by the organisation itself. For the agricultural NOGs analysed, this ratio ranged from $22.1 \%$ to $108.2 \%$ in 2017 . The organisations with a ratio of above $100 \%$ had accumulated financial resources that are sufficient to cover one-year expenditures.

The above-mentioned ratios could be calculated using a relatively small amount of data that are available publicly. The data shown in annual report annexes have to be employed as well. Even though the legal framework for accounting for associations and foundations prescribes that annexes are also part of an annual report, yet publicly available sources agricultural NGO annual reports - had no annexes. In a situation where extra accounting data are available, it is possible to do a detailed analysis and accurately identify the weaknesses and strengths of the organisation. However, it has to be taken into account that just like enterprises, organisations compete against one another, and they are not interested in disclosing more information in their annual reports than it is required by the relevant legal framework.

A detailed financial analysis involves various structural calculations that mainly pertain to a detailed analysis of revenues and expenditures. The need to do a detailed analysis is determined by revenue and expenditure statement items such as other revenue and other expenditure. For the NGOs analysed in the study by the Latvian Civic Alliance (2016), the mentioned items represented $34.5 \%$ and $64.3 \%$, respectively. In contrast, for only a few agricultural NGOs analysed the item Other expenditure reached $45 \%$, while the item Other expenditure was considerable for all the NGOs, and in some instances even reached $80 \%$. Both items represent a significant amount of funds that could not be assessed using publicly available information in relation to whether the funds are spent on the goals of organisations and how effectively the funds have been spent. 
The existence and activity of any individual is characterised by disposable funds. Accounting regulations for the NGO sector prescribe that revenues have to be classified into six categories: membership fees; donations and gifts; inheritance; government subsidies; revenues from economic activity; other revenue. The sources of revenue could be diverse; therefore, it is important to verify the STABILITY OF THE SOURCES OF REVENUE. This is a typical structural ratio. It is expressed as a ratio of revenue to total revenue for each source of revenue, and it is compared with that for the previous period.

The sources and amounts of finance for NGOs can vary from year to year; therefore, this ratio allows assessing safe sources of revenue and making financial forecasts. There is no range set for this ratio, and it has to be assessed for each individual organisation. A too high ratio for some source of finance might create problems concerning the solvency of the organisation in case the amount of finance received from this source decreases. It is important to assess the stability of sources of finance when drawing up a budget for the next year and planning projects. According to the study by the Latvian Civic Alliance (2016), the key sources of finance for NGOs in Latvia are economic activity and other revenue. Their economic activity involves consultations, training, holding educational and NGO popularisation activities, etc. Other sources of finance are project activities, property management, contract work, etc. Government subsidies received by the NGO sector made up $6.8 \%$ of their total finance in 2014. Even though the NGOs surveyed by the Latvian Civic Alliance (2016) indicated membership fees as their key source of finance, this source of finance comprised only $1.7 \%$ of the total revenue of the NGOs analysed, yet remuneration accounted for $25 \%$ of their total expenditures, exceeding the amount of membership fees approximately 14.6-fold. In view of the low participation of the public in NGOs, the NGOs are not able to fully cover their costs by only their membership fees and pay motivational salaries to their employees without using other sources of finance.

EFFICIENCY OF REVENUES have to assess the NGOs, i.e. how much resources have been invested to attract the finances - the cost of attracting the revenues is subtracted from the amount of the revenues acquired, thereby calculating the net amount. The second way of calculation represents a ratio of costs incurred to revenues acquired.

EFFICIENCY OF A PROGRAMME, Similarly to revenue analyses, the implemented by the NGO, which indicates the share of cost of a particular activity in total cost, has to be also assessed. This ratio could be calculated if the cost of a particular activity is known; the cost compared with the result of the activity allows assessing the efficiency of the activity or the sufficiency of finances for the further implementation of the activity. The ratio is calculated by dividing expenditure on a particular programme by total expenditure. Most often, this ratio is used by an NGO's members to assess their satisfaction with the results achieved and make a decision on their further membership in the NGO. Target donations could be made in order to allocate funds only to a particular programme. The efficiency of a programme could not always be determined by means of a ratio; most often, in the NGO sector it has to be assessed based on the work done.

NGOs receive various subsidies from the government as well as tax relief (Yetman \& Yetman, 2016); therefore, the government is interested in receiving feedback and making sure the governmentfunded activities contribute to employment, NGO sector development, public participation, tax revenues etc. Communicating with national institutions about the role of the NGO sector, the NGOs can defend their interests by means of financial analyses of taxes paid to the government, specifying the amounts of total revenue, total expenditure or total subsidies that are paid back to the government as labour taxes, the value added tax, etc.

Possibilities of financial analysis results compared

To perform a complete analysis, conclusions and explanations have to be provided as well as factors affecting or being able to affect performance have to be identified in addition to the ratios calculated. Drawing up conclusions, the specifics of the NGO sector or the organisation have to be taken into consideration. The results have to be compared with the average in the NGO sector or benchmarked against those for other organisations, yet the comparison with other industries or legal forms of business have to be done cautiously.

In business, where more statistics are available, a comparison is easier to do, and some institutions responsible for statistics regularly perform calculations of averages for industries. At present in the NGO sector, however, a comparison is possible only if performing analyses of individual organisations. The databases of Lursoft and the CSB provide diverse information on legal entities - their annual reports and balance sheets -, yet the information is classified according to the NACE 2.rev classification, and a shortcoming of this system is that it is not possible to select annual report information by legal form - an enterprise or NGO. Theoretically, aggregate data on the NGO sector could be acquired from the $S$ section of the NACE classification, yet it has to be taken into account that the $S$ section has three divisions, and NGOs are included in the section $S 94$ - activities of public, political and other organisations - without providing a more detailed classification up to the level of class (with a four digit numerical code) or 
by kind of legal entities. According to the 2017 data on economically active entities in Latvia, the section $S$ was represented by 23.7 thousand legal entities, of which $20.5 \%$ were associations and foundations, while $62.9 \%$ were self-employed individuals and $16.6 \%$ were other legal entities that, unlike NGOs, had other economic activity purposes, including profit-making, which considerably changed the composition of financial indicators for the entities included in section $S$. Even though the $C S B$ provides financial data on legal entities included in section $S$, division 94, this division reported on only 4055 economically active nongovernmental organisations or $38 \%$ of the total, which was a too low proportion to characterise the overall financial situation in the NGO sector. Other NGOs are classified under the other NACE sections, which was due to Cabinet Regulation No.779 of 22 December 2015 Regulations Regarding the Classification of Associations and Foundations; the purpose of the regulation was to classify NGOs by a kind of activity and to contribute to the quality of statistics and organisational transparency in accordance with the uniform legal entity classification standards. A potential solution is to compliment the statistical sources by one more statistic that classifies legal entities by kind of activity.

The Latvian Civic Alliance does regular studies on the NGO sector, and in 2015 it surveyed 423 NGO representatives and analysed 99 NGO annual reports. The NGOs were selected from each region of Latvia and represented 11 kinds of activity. However, as indicated by the Latvian Civic Alliance itself, the financial analysis results differed from the survey results. This means that the number of NGOs analysed by the Latvian Civic Alliance was too small to perform a high-quality analysis and identify averages for the NGO sector.

\section{Conclusions}

1. Despite globalisation, changes in the economy and developments in the world, financial analysis is still necessary for stakeholders to get insight into the financial condition of the entity analysed. The methodologies of analysis and basic calculation functions are the same throughout the world, which are adapted to the accounting system of each particular country and the legal form of the entity analysed.

2. The publicly available associations and foundations annual reports provide with much less explanation as enterprises annual reports, but the financial analysis methods for associations and foundations are equally effective, which contribute to the transparency of NGO activities and the public's trust in them.

3. NGOs receive a lot of benefits/ government relief comparing with enterprises, that is why the performance analysis is a way how to show that the status of NGOs is used fairly; no hidden profitmaking activity; funding's are spent under control; and organisations are able to perform liabilities.

4. Financial analysis is one of the complex analysis methods whereby relevant calculations are performed and conclusions are drawn, and it is important to compare the results with averages for the NGO sector or industries or benchmark them against those for other organisations. To make a comparison with the average in the NGO sector, the CSB of Latvia has to complement its statistical selection criteria by a criterion of legal forms.

\section{References}

1. Ashley, A., \& Faulk, L. (2010). Nonprofit competition in the grants marketplace: Exploring the relationship between nonprofit financial ratios and grant amount. Nonprofit Management and Leadership, Vol. 21, Issue 1, pp. 43-57. DOI: 10.1002/nml.20011.

2. Bogužs, J. (2010). Problēmas uzñèmuma saimnieciskās darbības finanšu koeficientu izmantošanā biedrību un nodibinājumu darbības analīzei (Problems for Using Enterprise Financial Ratios for Evaluating the Efficiency of Associations and Foundations). Valsts, uzņēmējdarbība, cilvēki - inovatīvas iespējas un risinājumi Latvijā un citās Eiropas valstīs, Latvija, Rīga, 18. jūnijs, 2010. Karjeras Izaugsmes Koledža, 22. -33. lpp. (in Latvian)

3. Chiang, A. (2016). 5 Financial KPIs for Non-profit Organizations. Retrieved March 3, 2019, from https:// www.unit4.com/us/blog/2016/07/5-financial-kpis-for-non-profit-organizations.

4. Eccles, R.G. (2008). Harvard Business Review on Measuring Corporate Performance. Rīga: Lietišḳās informācijas dienests.

5. Haber, J., \& Schryver, C. (2019). How to Create Key Performance Indicators. CPA Journal, 89(4), 24-30.

6. Hammond, C. (2015). 9 Ratios to Help Measure Your Not-For-Profit's Financial Health. Retrieved March 3, 2019, from http://info.cbiztofias.com/the-new-england-not-for-profit-advisor/nine-ratios-to-helpmeasure-your-not-for-profits-financial-health.

7. Holman, C.A., Ihrke, M.D., \& Grasse, J.N. (2010). The Analysis of Key Financial Ratios in Nonprofit Management. Retrieved March 3, 2019, from https://static1.squarespace.com/static/533c8365e4b089b274

8. aa090c/t/56324270e4b0f1714bc22121/1446134384522/Nonprofit+Presentation+on+Ratios.pdf. 
9. Jegers, M. (2013). Do nonprofit organisations manage earnings? An empirical study. Voluntas, 24, 953-968. DOI: $10.1007 / \mathrm{s} 11266-012-9291-\mathrm{z}$.

10. Latvian Civic Alliance. (2016). The Review of the NGO Sector in Latvia 2015. Retrieved March 3, 2019, from http:/www.nvo.lv/site/attachments/29/04/2016/NVO_PARSKATS_EN_20.04-2.pdf.

11. Leibus, I., Pētersone, I., Jesemčika, A., Svarinska, A., \& Grigorjeva, R. (2018). Finanšu grāmatvedība (Financial Accounting). Updated, $2^{\text {nd }}$ edition. Rīga: Lietišḳās informācijas dienests. (in Latvian)

12. Morris, M.J. (2011). Starting a Successful Business. London, UK.: Kogan Page Ltd.

13. Phillips, F., Libby, R., Libby, P., \& Mackintosh, B. (2012). Fundamentals of Financial Accounting. Toronto, Canada: McGraw-Hill Ryerson, pp. 12-568.

14. Regulation Regarding the Associations' and Foundations' Annual Financial Statements. (2006). Republic of Latvia, Cabinet Regulation No. 808, Adopted 3. October 2006. Retrieved March 3, 2019, from https:// likumi.lv/doc.php?id=145113.

15. Regulation Regarding the Conduct and Organisation of Accounting. (2003). Republic of Latvia, Cabinet Regulation No. 585, Adopted 21. October 2003. Retrieved March 3, 2019, from https://likumi.lv/doc. php?id=80418.

16. Robinson, R.T. (2009). International Financial Statement Analysis. Hoboken, N.J.: Wiley, pp. 2-14.

17. Tian, S., \& Yu, Y. (2017). Financial ratios and bankruptcy predictions: An international evidence. International Review of Economics \& Finance, Volume 51, 510-526. DOI: 10.1016/j.iref.2017.07.025

18. The Associations and Foundations Law. (2004) Law of the Republic of Latvia. Retrieved March 3, 2019, from https://likumi.lv/doc.php?id=81050.

19. Yetman, M., \& Yetman, R. (2012). The effects of governance on the accuracy of charitable expenses reported by nonprofit organizations. Contemporary Accounting Research, 29, 738-767. DOI: 10.1111/j.19113846.2011.01121.x.

20. Zemkopības ministrija. (2017). Pielikums Zemkopības ministrijas 08.11.2017 rīkojumam Nr.155 Lauksaimnieku nevalstisko organizāciju konsultatīvās padomes nolikums (Regulation of the Agricultural Organisations Advisory Board - Annex of the Warrant No. 155 08.11.2017 of the Ministry of Agriculture of the Republic of Latvia). Retrieved March 3, 2019, from https://www.zm.gov.lv/public/ck/files/ZM/ lauksaimnieciba/ZM_NVOpadome_Rik_piel_07_11_2017.pdf. (in Latvian) 